\title{
Development Learning Tools with CTL Approach for Elementary School Students
}

\author{
Rizky Nugroho, Mustaji,Suhanadji \\ Universitas Negeri Surabaya \\ Surabaya, Indonesia \\ rizky.nugroz@gmail.com
}

\begin{abstract}
This research aims to produce learning tools with a Contextual Teaching and Learning approach (CTL) that is valid, practical, and effective for fourth graders in elementary school. This research is a development study using 4D development model which includes four stages of define, design, develop and disseminate. The result of the research shows that learning tools are valid with the very good category by the validator. Implementation of learning tools can be done with very good category and students responses to learning tools are in the very good category. There are differences in learning motivation and significant learning result between experimental classes using learning tools with Contextual Teaching and Learning approaches and control classes that do not use learning tools result of development. Based on the results of the study, it can be concluded that the development of learning tools with Contextual Teaching and Learning approach fulfills the valid, practical, and effective criteria.
\end{abstract}

Keywords - Learning Tools, Contextual Teaching and
Learning

\section{INTRODUCTION}

Learning is a process of interaction between the components of the learning system [1]. In the learning process, the main components are teachers and students. Teachers as actors who manage the learning process from opening lessons to closing lessons. Student as subject receiving material that delivered by the teacher. Conducive learning activities can be seen in the reciprocal relationship between teachers and students. Learning activities is a key element in the educational process in schools, with teachers as key role-holders. Learning is a process to develop student potential. In this process, a teacher must have a learning plan that will apply in the learning process.

the Lesson plan was done by the teacher through learning tool arrangement. Learning should be designed as a learning tool that can be fun and interesting so that students will be motivated in following the learning activities delivered by the teacher. Learning tools are things that must be monitored so that the learning implementation more directed to achieve the expected competence [2]. Learning tools that required in managing the learning process can be as follows: Student textbook, Syllabus, Lesson Plan, Student Learning Sheet, Evaluation Sheet or Learning Result Test), and Learning media [3]. Learning tools in teaching and learning activities are so important so that each teacher should be able to develop learning tools.

Based on the results of observations in fourth-grade student of SDN Hendrosari, Menganti District, Gresik, there are obstacles in the learning process namely teachers still use the lecture method to deliver learning. Teachers have not used the appropriate learning media, so students lack interested in learning. Learning was still centered on the teacher so that learning activities become less effective because students become passive since they only hear information from teachers. Students are less motivated in following the lesson, there are still students who play alone, students do not pay attention to the teacher's explanation even in the class, and the students disturb peer who is paying attention to the teacher. Besides the student's learning result that has not been maximized, many students who get the score under the minimum completeness criterion that has been set to 70 .

Based on the above problems, teachers need to design learning tools using innovative learning approach. One of the innovative learning that can be applied is Contextual Teaching and Learning approach. Contextual Teaching and Learning is one of the strategies offered in learning to improve learning motivation and learning result. Contextual Teaching and Learning is a holistic educational process aimed at motivating students to understand the meaning of the subject matter they learned by linking the material to the context of everyday life [4]. With the concept, it is expected that students will be more motivated in the learning process as well as the learning they experience will be more meaningful.

Contextual Teaching and Learning as a way of introducing learning materials using various active learning techniques that designed to help students connect what they already know to what they want to learn, and to build new knowledge from analysis and synthesis of learning process [5]. Learning by Contextual Teaching and Learning approach, students are actively invited to connect the content of the learning materials to the context of the student's daily life, thus bringing the understanding and meaning intact [6].

Contextual Teaching and Learning in a conception of teaching and learning helps teachers relate the content of subject matter to real-world situations. On the other hand, CTL defined the concepts as an innovative instructional process that helps students connect the content they have learned to the life context in with that content could be used [7]. This is in line 
with the theory of Ausubel which suggests that to optimize the acquisition, organizing, and disclosure of new knowledge can be done by making new knowledge meaningful to students. Meaningful learning can be done by linking to the knowledge already possessed by previous students [8]. In Contextual Teaching and Learning approach, there are seven main components namely: constructivism, questioning, inquiry, learning community, modeling, reflection and authentic assessment [9]. These components encourage the student to full involvement in finding their knowledge so that students will be more motivated in following the learning activities and improving residual understanding of the learning material.

The results of the study from Anggraini et al [10] showed that the learning components contained in the Contextual Teaching and Learning approach that includes constructivism, inquiry, questioning, community learning, and modeling have been shown to improve student's motivation and become better than before. Further research results from Amuntu et al. [11] showed that student learning result is improved. The experience that students get from Contextual Teaching and Learning learning makes it easier for students to understand the teaching materials. Student motivation for Contextual Teaching and Learning learning also increased. Students excited to follow learning because it applied in relation to the daily life of students. Based on the results of previous research, it can be concluded that the Contextual Teaching and Learning approach can increase student's motivation in following the learning so that student learning result become increasing.

In this study, the learning tool that developed is a learning tool for the region where I live theme. The theme of the region where I live is one of the theme materials taught in elementary school in fourth-grade elementary school. Contextual Teaching and Learning approach to this theme is very appropriate to apply because the material is directly related to the environment. With the Contextual Teaching and Learning approach, students will be invited to some places in the neighborhood around the school environment. This is in line with Piaget's theory which states that the level of intellectual development of elementary school children who are still in the concrete operational stage. At this stage, children cannot think abstractly [12]. The learning process will be more successful if adjusted to the cognitive development of students. Teachers should provide many stimuli to students to interact with their environment and actively seek and find things from the environment [8].

\section{METHOD}

This type of research was Research and Development. Research and Development is a research method used to produce a particular product, and test the effectiveness of the product [13]. The product that produced by this research is a learning tool by using Contextual Teaching and Learning approach on the theme of the region where I live theme subtheme of my living environment for fourth-grade students of elementary school. Learning tool development model used in this research was the 4-D model. The 4-D development Model (Four D) is a model of learning tool development. Research and Development steps abbreviated as 4-D, which is the extension of Define, Design, Development and Disseminate [14].

The test subject in this development research was the fourth-grade student of SDN Hendrosari in the $2^{\text {nd }}$ semester of academic year 2017/2018. The Subject of Test 1 (limited testing) were 10 students consisting of 5 students of Class IV-A and 5 students of Class IV-B that selected at random. The experiment subjects of Test 2 (field testing) were 40 students consisting of 20 students of class IV-A as the experimental class and 20 students of class IV-B as control class. The product testing was conducted in two stages, namely the first test (small group) and second test (field testing). Field testing conducted by using non-equivalent control group design. This study there are two groups of experiments and controls, then delivered pretest, different treatment, and posttest. It aimed to know the difference between the experimental class and the control class before and after being given different treatment [13].

Instruments for collecting data used in this research were validation sheet, observation sheet, and questionnaire, learning result test. The analysis of learning tools feasibility using Contextual Teaching and Learning approach was done through validation sheet using the Likert scale. The validation results then converted into percentages and classified into several interpretation categories. The analysis of learning tool practicality was done by using Contextual Teaching and Learning approach that conducted through observation sheet on the learning process, student activity, and student response questionnaire. The results of the observation sheet and the questionnaire then converted into percentages classified into several categories of interpretation. Furthermore, the analysis of the learning tools effectiveness using Contextual Teaching and Learning approach can be seen through the questionnaire of learning motivation and student learning result test.

\section{RESULTS AND DISCUSSION}

The result of the learning tool feasibility using Contextual Teaching and Learning approach was obtained from the validation sheet of the learning tool that filled by the validator. The results of validation from learning tools include the lesson plan, student teaching materials, student worksheet, and learning results test that presented in table I.

TABLE I. VALIDATION RESULT

\begin{tabular}{|l|c|c|}
\hline \multicolumn{1}{|c|}{ Validation Sheet } & Percentage & CategorY \\
\hline Lesson Plan & 91 & Very Good \\
\hline Worksheet & 86 & Very Good \\
\hline Student Teaching Materials & 88 & Very Good \\
\hline Learning Outcome Test & 86 & Very Good \\
\hline
\end{tabular}

Based on the data in table I, it can be concluded that learning tools using Contextual Teaching and Learning approach was feasible to be used in the learning process with the very good category. 
The practicality of instructional tools using Contextual Teaching and Learning approach can be seen from the observation sheet of the learning implementation and response questionnaires filled by the students. The result of the observation sheet of learning implementation is presented in Table II.

TABLE II. THE OBSERVATION RESULT OF LEARNING PROCESS

\begin{tabular}{|c|c|c|}
\hline Meeting to & Percentage & Category \\
\hline 1 & 88 & Very Good \\
\hline 2 & 88 & Very Good \\
\hline 3 & 89 & Very Good \\
\hline 4 & 90 & Very Good \\
\hline 5 & 91 & Very Good \\
\hline 6 & 92 & Very Good \\
\hline Mean & 89 & Very Good \\
\hline
\end{tabular}

Based on the data in table II, it can be concluded that the implementation of learning using Contextual Teaching and Learning approach belong in the very good category. The results of media practicability that taken from the respondents' questionnaires are presented in Table III.

TABLE III. THE RESULT OF LEARNING TOOLS PRACTICALITY QUESTIONNAIRE

\begin{tabular}{|c|c|c|c|}
\hline Trial & $\begin{array}{c}\text { Number of } \\
\text { the } \\
\text { Student's }\end{array}$ & Percentage & Category \\
\hline $\begin{array}{c}\text { Limited } \\
\text { Testing }\end{array}$ & 10 & 89 & Very Good \\
\hline $\begin{array}{c}\text { Field } \\
\text { Testing }\end{array}$ & 20 & 92 & Very Good \\
\hline
\end{tabular}

Based on the data in Table III, it can be concluded that learning tools using Contextual Teaching and Learning approach is categorized as very good or practical to be used in the learning process.

The effectiveness of instructional tools was obtained from the results of the student's motivation and learning result. The result of pretest and posttest will be tested by t-test to know the effectiveness of the learning tool using Contextual Teaching and Learning approach. However, before it tested using the $\mathrm{t}$ test, the first researcher test it using normality and homogeneity test. Normality test and homogeneity test was done to know if the data were normally distributed or not. Normality test was done by using the Shapiro-Wilk statistic test with SPSS 23 program. The test criterion was if the value of significance (p) obtained more than $\alpha=0,05$ then the data has the normal distribution and if the value of significance obtained is less than $\alpha=0,05$ then the data distribution is not normally distributed. The result of the normality test of learning motivation data and student learning result is presented in Table IV.
TABLE IV. THE RESULT OF NORMALITY TEST

\begin{tabular}{|c|c|c|c|c|}
\hline Class & Normality Test & Sig & $\alpha$ & $\begin{array}{c}\text { Test } \\
\text { Decision }\end{array}$ \\
\hline \multirow{4}{*}{ Experimental } & $\begin{array}{c}\text { Pretest } \\
\text { Learning } \\
\text { Motivation }\end{array}$ & 0,122 & 0,05 & Normally \\
\hline & $\begin{array}{c}\text { Posttest } \\
\text { Learning } \\
\text { Motivation }\end{array}$ & 0,434 & 0,05 & Normally \\
\hline & $\begin{array}{c}\text { Pretest } \\
\text { Learning } \\
\text { Result }\end{array}$ & 0,430 & 0,05 & Normally \\
\hline & $\begin{array}{c}\text { Posttest } \\
\text { Learning } \\
\text { Result }\end{array}$ & 0,082 & 0,05 & Normally \\
\hline \multirow{4}{*}{ Control } & $\begin{array}{c}\text { Pretest } \\
\text { Learning } \\
\text { Motivation } \\
\end{array}$ & 0,271 & 0,05 & Normally \\
\hline & $\begin{array}{l}\text { Posttest } \\
\text { Learning } \\
\text { Motivation }\end{array}$ & 0,221 & 0,05 & Normally \\
\hline & $\begin{array}{c}\text { Pretest } \\
\text { Learning } \\
\text { Result }\end{array}$ & 0,199 & 0,05 & Normally \\
\hline & $\begin{array}{l}\text { Posttest } \\
\text { Learning } \\
\text { Result }\end{array}$ & 0,356 & 0,05 & Normally \\
\hline
\end{tabular}

Based on the data in Table $\mathrm{V}$, it can be concluded that the data were normally distributed. After conducting the normality test, the next step was to test homogeneity to find out whether the two classes were homogeneous or not. The homogeneity test was performed using the statistical test of Lavene Statistic with the aid of program SPSS 23. The test criterion was if the significance value (p) obtained over $\alpha=0.05$ then the data has the homogeneous variant and if the significance value obtained is less than $\alpha=0,05$ then it has a non-homogeneous variant. Homogeneity test results of motivation data and student learning result is presented in Table $\mathrm{V}$.

TABLE V. THE RESULT OF HOMOGENEITY TEST

\begin{tabular}{|c|c|c|c|}
\hline $\begin{array}{c}\text { Homogeneity } \\
\text { Test }\end{array}$ & Sig & $\alpha$ & Test Decision \\
\hline $\begin{array}{c}\text { Pretest } \\
\text { Learning } \\
\text { Motivation }\end{array}$ & 0,131 & 0,05 & Homogenous \\
\hline $\begin{array}{c}\text { Posttest } \\
\text { Learning } \\
\text { Motivation }\end{array}$ & 0,804 & 0,05 & Homogenous \\
\hline $\begin{array}{c}\text { Pretest } \\
\text { Learning Result }\end{array}$ & 0,926 & 0,05 & Homogenous \\
\hline $\begin{array}{c}\text { Posttest } \\
\text { Learning Result }\end{array}$ & 0,318 & 0,05 & Homogenous \\
\hline
\end{tabular}

Based on the data in Table V, it can be concluded that the experimental and control classes were homogeneous. After knowing that the data distributed in both classes was normal and homogeneous, the next step is to do a t-test. The t-test was performed using the independent t-test sample statistic test with the help of SPSS 23. The test criterion was if the sig value. (2tailed) obtained over $\alpha=0.05$ then Ho is accepted and if the value is a sig. (2-tailed) obtained less than $\alpha=0.05$ Ho is rejected. The result of the t-test of motivation data and student learning result is presented in Table VII. 
TABLE VI. THE RESULT OF T-TEST

\begin{tabular}{|c|c|c|c|}
\hline T-Test & $\begin{array}{c}\text { Sig } \\
\text { (2-tailed) }\end{array}$ & $\alpha$ & Test Decision \\
\hline $\begin{array}{c}\text { Pretest Learning } \\
\text { Motivation }\end{array}$ & 0,618 & 0,05 & Ho accepted \\
\hline $\begin{array}{c}\text { Pretest Learning } \\
\text { Result }\end{array}$ & 0,597 & 0,05 & Ho accepted \\
\hline $\begin{array}{c}\text { Posttest Learning } \\
\text { Motivation }\end{array}$ & 0,000 & 0,05 & Ho rejected \\
\hline $\begin{array}{c}\text { Posttest Learning } \\
\text { Result }\end{array}$ & 0,0001 & 0,05 & Ho rejected \\
\hline
\end{tabular}

Based on the data in Table VII, it is known that t-test result of learning motivation data using a t-test between the experimental class and control class shows that the sig value. (2-tailed) learning motivation pretest of $0.618>0.05$ then the test decision is Ho accepted and Ha rejected, while the value of sig. (2-tailed) pretest student learning results of $0.597>0.05$ then the test decision is Ho accepted and Ha rejected. Based on these results, it can be concluded there is no significant difference between motivation and student learning outcomes in the experimental class that implement the learning using Contextual Teaching and Learning approach with the control class that implements the learning without Contextual Teaching and Learning approach.

While t-test result of learning motivation data using the ttest between the experiment class and control class showed that the sig value. (2-tailed) student's learning motivation posttest was as big as $0.001>0.05$ then the test decision is Ho rejected and Ha accepted, while the sig value. (2-tailed) posttest student learning result was $0.001>0.05$ then the test decision is Ho rejected and Ha accepted. Based on these results, it can be concluded there is a significant difference between motivation and student learning result in the experimental class that implements the learning using Contextual Teaching and Learning approach with the control class that implements the learning without using Contextual Teaching and Learning approach. Thus, learning tools using Contextual Teaching and Learning approach proved to be effective in improving student's motivation and learning result.

Based on the results of the study, students' learning motivation in the experimental class increased learning motivation higher than the control group because they received learning with the Contextual Teaching and Learning approach. Contextual Teaching and Learning approach is an approach that applies various variations of learning activities so that students are more motivated in participating in learning activities. Contextual Teaching and Learning approach is a holistic educational process and aims to motivate students to understand the meaning of the subject matter learned by linking the material to the context of everyday life. In learning Contextual Teaching and Learning there are activities such as modeling, question and answer, learning communities that involve the activeness of students in linking material with student experience, so students are more motivated in participating in learning activities [4]. Interesting learning such as using demonstration, questions or activities that stimulate student curiosity, simulation, lessons based on students' own interests and activities that require cooperation can be applied by the teacher to enhance learning motivation student [15].
The results also showed that the experimental class experienced a higher increase in learning result than the control class. Learning by using the Contextual Teaching and Learning learning model on the theme my hometown can improve student learning result. In learning using the Contextual Teaching and Learning approach, teachers develop subject matter by constructing new students 'knowledge and linking it to students' lives through question and answer about the material being discussed. Constructivism in the Contextual Teaching and Learning approach emphasizes that students are very important to be directly involved in building their own knowledge so that the learning process that occurs is more student-centered [16]. This is according to Ausubel's theory which argues that to optimize acquisition, organization, and disclosure of new knowledge can be done by making new knowledge meaningful to students. This can be done by the teacher by relating to the knowledge that has been owned by the previous student. Before students are given new material, prior knowledge must be well structured so that new knowledge can enter the students' knowledge structure and be processed into new cognitive structures [8].

\section{CONCLUSION}

Based on the research results and discussion, it can be concluded that: (1) the developed learning tools using Contextual Teaching and Learning approach is considered feasible and can be used in the learning based on expert's assessment results; (2) the developed learning tools using Contextual Teaching and Learning approach is considered practice based on analysis result of learning implementation observation sheet and student's response questionnaire; (3) the developed learning tools using Contextual Teaching and Learning approach is considered to be effective based on the improvement of learning motivation student's. (4) the developed learning tools using Contextual Teaching and Learning approach is considered to be effective based on the improvement of student's learning result.

\section{REFERENCES}

[1] Daryanto and Dwicahyono, A., Pengembangan Perangkat Pembelajaran. (Silabus, RPP, PHB Bahan Ajar), Yogyakarta: Gava Media, 2014.

[2] Rusman, Mengembangkan Profesionalitas Guru, Raja Grafindo Pustaka. Jakarta, 2012.

[3] Ibrahim, M dan Nur, M., Pengajaran Berdasarkan Masalah, Surabaya: University Press, 2003.

[4] Majid, Abdul, Strategi Pembelajaran. Bandung : PT Remaja Rosdakarya, 2013.

[5] Hudson, C. C. and Whisler, V., R., "Contextual Teaching and Learning for Practitioners”, Journal Systemics, Cybernetic and Informatics, vol. 6, no. 4, pp. 54-58, 2012.

[6] Johnson, Contextual Teaching and Learning: What It Is and Why It's Here to Stay, California: Corwin Press, Inc, 2002.

[7] Smith, Bettye P., Instructional Strategies in Family and Consumer Sciences: Implementing the Contextual Teaching and Learning Pedagogical Model, Journal of Family and Consumer Science Education, vol. 28, no. 1, pp. 23-38, 2010.

[8] Susanto, Ahmad, Pengembangan Pembelajaran IPS di Sekolah Dasar, Jakarta: Prenadamedia Group, 2014.

[9] Suprijono, Agus, Cooperative Learning Teori \& Aplikasi PAIKEM. Yogyakarta: Pustaka. Pelajar, 2012. 
[10] Anggraini, Tika, ett all, "The Difference of Ability to Ask, Scientific Attitude, Motivation Before and After Following Contextual Teaching and Learning Model”, Journal of Primary Education, vol. 6, no. 3, pp. 247-255, 2017.

[11] Amuntu, Santje, ett all, "Meningkatkan Motivasi dan Hasil Belajar Siswa Melalui Contextual Teaching And Learning Pada Tema Lingkungan Di Kelas II SDN 2 Talise”, E-Jurnal Mitra Sains, vol. 4, no, 3, pp. 28-34. 2016.

[12] Nursalim, Mochamad, ett all, Psikologi Pendidikan. Surabaya: Unesa. University Press, 2007.
[13] Sugiyono, Metode Penelitian Kuantitatif Kualitatif dan R\&D, Bandung: Alfabeta, 2012.

[14] Thiagarajan, S., Semmel, D. S., \& Semmel, M. L., Instructional Development for training Teachers of Exceptional Children, Bloomington Indiana: Indiana University, 1974.

[15] Wuryani, Sri Esti, Psikologi pendidikan, Jakarta: PT Gramedia Widiasarana, 2006.

[16] Sujana, Atep, Pendidikan IPA, Bandung: Rizqi Press, 2014 